\title{
Assessment of Tribological Properties of Single- and Double-Layer Pad Coatings Deposited onto Cultivator Points
}

\author{
Wiesław Wójcik', Marcin Barszcz ${ }^{2 *}$, Krzysztof Dziedzic², \\ Jarosław Kuzioła', Przemysław Kowalik ${ }^{1}$ \\ 1 Lublin University of Technology, Fundamentals of Technology Faculty, Department of Fundamental of \\ Technology, 38 Nadbystrzycka Street, 20-618 Lublin, Poland, e-mail: w.wojcik@pollub.pl, j.kuziola@pollub.pl. \\ 2 Lublin University of Technology, Electrical Engineering and Computer Science Faculty, Institute of Computer \\ Science, 36B Nadbystrzycka Street, 20-618 Lublin, Poland, e-mail: m.barszcz@pollub.pl,k.dziedzic@pollub.pl. \\ * Corresponding author's e-mail: m.barszcz@pollub.pl
}

\begin{abstract}
This paper investigates properties of single- and double-layer pad coatings deposited on cultivator points. The coatings were deposited by manual metal arc welding (MMA) with ESAB OK. 84.58 coated electrodes using an inverter welder, DEDRA DESi201. Tribological properties were determined with a THT 1000 tribometer. A ballon-disc friction pair was used. Experiments were performed in room temperature, with the sliding speed set equal to $0.3 \mathrm{~m} / \mathrm{s}$ and two loads: 5 and $20 \mathrm{~N}$. In addition, hardness was measured on the surface and in the cross section of samples by a Rockwell hardness test method (scale C). Surface roughness was measured before and after friction, and post-friction surface topography was examined under microscope. Impact strength tests of the coatings with single- and double layers of pads were performed. The tools and IT algorithms were used to collect and process the results of experimental research.
\end{abstract}

Keywords: wear, friction, coatings, welding.

\section{INTRODUCTION}

Farming machinery elements for soil cultivation are exposed to many external factors that may cause their failure. The surface layer of materials is the most prone to failure because it directly interacts with work environment, i.e. the soil and its components such as stones, gravel, sand, clay, etc. This layer is exposed to operational wear due to friction. The most dominant type of wear in this case is abrasive wear [1]. It consists in separation of small particles of the surface layer of material due to the friction of the above-mentioned work environment factors (that act as abrasive particles and are harder than the surface layer of the material) [2-4]. The wear of surface layers is caused by fundamental processes such as microcutting, scratching, chasing, shearing and the removal of surface microirregularities.
The abrasive wear rate of the surface layer of agricultural machine elements depends on the type of soil, its consistency, structure and humidity [5-6]. Soil is not structurally homogeneous by its very nature, so work conditions can change dynamically [7]. In addition, a mixture of fine particles of soil, stones, gravel, clay, etc. can lead to significant material reduction over a short period of time [9]. This process can also be intensified due to the presence of other substances in the soil, including [10-12]:

- chemically inactive substances (involved in sorption) that reduce mechanical strength of the surface layer of a material,

- corrosion-active substances (electrolytes, salt solutions) that act chemically or electrochemically,

- substances absorbed into the surface layer of a material that reduce its strength 
(hydrogen is the main substance absorbed into the surface layer).

The wear of agricultural machine elements also strongly depends on the properties of the surface layer of a material $[5,13]$. These properties have a decisive influence on the service life of these products [8]. In order to increase their service life, it is therefore necessary to reduce the wear of materials of frictional pairs $[14,15]$. To do so, it is necessary to ensure that the formed surface layer has properties that will significantly increase both tribological wear resistance and service life of construction materials [16]. One of the solutions is to use welding methods (pad welding) that enable modification of the chemical composition of a parent material by introducing various additional components. Pad welding can be used to improve the properties of newly manufactured elements or to regenerate worn parts by coating them with a metal layer of suitable chemical composition and thickness. The purpose of regeneration is to restore the original performance of machine parts [17-20]. Welding consumables are usually in the form of coated electrodes or flux-cored and flux-coated wires.

The most widely used materials are based on $\mathrm{Fe}, \mathrm{Ti}, \mathrm{Co}, \mathrm{Ni}$ that are alloyed with different chemical elements such as $\mathrm{Cr}, \mathrm{B}, \mathrm{Ti}, \mathrm{Si}, \mathrm{Mo}, \mathrm{Mn}$, $\mathrm{W}, \mathrm{V}, \mathrm{Nb}$. They lead to changes in mechanical, tribological and corrosive properties [21-23]. Due to economic reasons, it is recommended to use Fe-based welding consumables. They include alloys such as Fe-Mn-CB, Fe-C-Cr-B, Fe-C-Cr, Fe-C-Cr-Ti-B, Fe-C-Cr-Ti, Fe-C-Cr-Mn-Ti, $\mathrm{Fe}-\mathrm{C}-\mathrm{Mn}-\mathrm{Ti}, \quad \mathrm{Fe}-\mathrm{C}-\mathrm{Cr}-\mathrm{WV}, \quad \mathrm{Fe}-\mathrm{C}-\mathrm{Cr}-\mathrm{Ni}$, $\mathrm{Fe}-\mathrm{Cr}-\mathrm{C}-\mathrm{Nb}$ [22-25].

In the article [26] is studied experimentally the effect of coating thickness and substrate roughness on the tool wear in turning. TiAlN coating of various thicknesses was applied on tungsten carbide (WC) tool substrate having various surface roughnesses. The tool wear was measured following a fixed cutting distance and speed tests. In general, when plotting the wear vs. coating thickness alone or vs. substrate roughness alone a trend of decreasing wear with either increasing coating thickness or substrate roughness is observed.

In recent years, one can observe a growing tendency to develop materials that ensure long service life of machine elements in farming equipment [27] and are cost-effective at the same time. In line with this tendency, this paper investigates tribological properties of single- and double-layer pad coatings deposited (by manual metal arc welding) on cultivator points with Fe-based coated electrodes. The MMA welding method and Fe-based coated electrodes were used in the study due to economic reasons and easy access to welding tools.

\section{MATERIALS AND METHODS}

Tests were performed on coatings deposited onto the surface of cultivator points made of $38 \mathrm{GSA}$ steel, with dimensions of $210 \times 40 \mathrm{~mm}$ (Tab. 1). The coatings were deposited by manual metal arc welding using ESAB OK 84.58 coated electrodes with a diameter of $4 \mathrm{~mm}$. They are hardfacing electrodes depositing a semi-corrosion-resistant martensitic steel. According to the manufacturer, the peak hardness should be achieved even in the first pass, regardless of the applied cooling rate. These electrodes are specially suitable for hardfacing parts that are exposed to abrasive and impact wear, such as farming equipment, forestry tools, loading machines and mixers. The chemical composition of the electrode is given in Table 1. Welding was performed with an inverter welder (at 150A welding current). Single and double layers of pads were deposited. After that, samples for laboratory tests were prepared; they were shaped as $30 \mathrm{~mm}$ diameter and 6 and $20 \mathrm{~mm}$ thickness discs and $55 \times 10 \times 10 \mathrm{~mm}$ rectangles. Hardness, impact strength and roughness measurements as well as tribological tests and microscopic examination of the friction surface were carried out.

Hardness measurement were made by a Rockwell $\mathrm{C}$ scale test using a conical diamond indenter with $120^{\circ}$ cone angle. The samples were loaded to a preload of $98 \mathrm{~N}$ and a total load of $1471 \mathrm{~N}$.

Tribological tests were conducted on a hightemperature tribometer, Anton Parr THT 1000, shown in Fig. 1a. The tests were conducted in

Table 1. Chemical composition of 38GSA steel and OK 84.58 electrode

\begin{tabular}{|l|c|c|c|c|c|}
\hline \multirow{2}{*}{ Electrode } & \multicolumn{5}{|c|}{ Element (wt.\%) } \\
\cline { 2 - 6 } & $\mathrm{Mn}$ & $\mathrm{C}$ & $\mathrm{Cr}$ & $\mathrm{Si}$ & $\mathrm{Fe}$ \\
\hline 38GSA Steel & 0,91 & 0,35 & 0,15 & 0,85 & residue \\
\hline $\begin{array}{l}\text { ESAB } \\
\text { OK. 84.58 }\end{array}$ & 0,7 & 0,7 & 10 & 0,6 & residue \\
\hline
\end{tabular}


accordance with ASTM G133 and G-99. The ballon-disc configuration was used, Fig. 1b. Samples had the shape of a disc with a diameter of $30 \mathrm{~mm}$ and a height of $6 \mathrm{~mm}$. 100Cr6 steel balls with a diameter of $6 \mathrm{~mm}$ were used as counter bodies. In the tribological tests, loads of $5 \mathrm{~N}$ and $20 \mathrm{~N}$ were applied. The loads were selected to simulate light and heavy working conditions of the cultivating unit's coatings. Load $5 \mathrm{~N}$ - light working conditions, $20 \mathrm{~N}-$ hard working conditions. The tests were conducted with a sliding speed of $0.3 \mathrm{~m} / \mathrm{s}$ and a radius of $4 \mathrm{~mm}$. The total sliding distance was set equal to $200 \mathrm{~m}$. Temperature was measured with a thermocouple at $2 \mathrm{~mm}$ from the surface of friction (actual temperature of the interface and the sample could reach higher values). Variations in the coefficient of friction, friction and temperature were measured in the tests. The frequency of data collection was $10 \mathrm{~Hz}$.

Taking into account load and friction path, the wear rate of the frictional pair was determined according to ASTM G133 with Equation (1).

$$
w_{d}=\frac{V_{f}}{F_{n} \times l}
$$

where: $w_{d}$-wear rate,

$$
\begin{aligned}
& V_{f}-\text { volume wear, } \\
& F_{n}-\text { load, } \\
& l \text {-friction path (distance). }
\end{aligned}
$$

Sample wear is measured by determining volume wear in the form of a wear trace resulting from interaction with the counterbody. For this purpose, measurements were made in an area perpendicular to the sample wear trace on the circumference of the sample (10 measurement points) with a contact profilometer, Surtronic $3+$. The measuring length was set equal to $4 \mathrm{~mm}$.
Volume wear was determined as the product of the average cross-sectional area of the track and the length of the stroke obtained from the ball-ondisc test according to Equation (2).

$$
V_{f}=A \times L
$$

where: $V_{f}$-volume wear,

$A$ - average cross-sectional area of the track,

$L$ - length of the stroke.

The wear of the counterbody was calculated by measuring the diameters of ball wear with a metallographic microscope, by Equations (3) and (4).

$$
\begin{gathered}
V=\frac{\pi h^{2}}{3}(3 r-h) \\
h=r-\sqrt{r^{2}-\left(\frac{d}{2}\right)^{2}}
\end{gathered}
$$

where: $r$ - ball radius $(3 \mathrm{~mm})$,

$h$ - ball height,

$d-$ ball diameter (experimentally measured).

Following the tribological tests, surface wear was measured. In order to analyse obtained results, surfaces of the samples and counter bodies were examined. First, surface roughness parameters were examined; they were measured before and after the tribological tests using a Surtronic $3+$ roughness gauge. After that, microscopic examination was performed. A scanning electron microscope, FEI Quanta 3D, was used to examine the friction surface topography. Wear trace images were recorded in a High Vacuum mode (pressure $<6 \cdot 10^{-4} \mathrm{~Pa}$ ) with $10 \mathrm{kV}$.

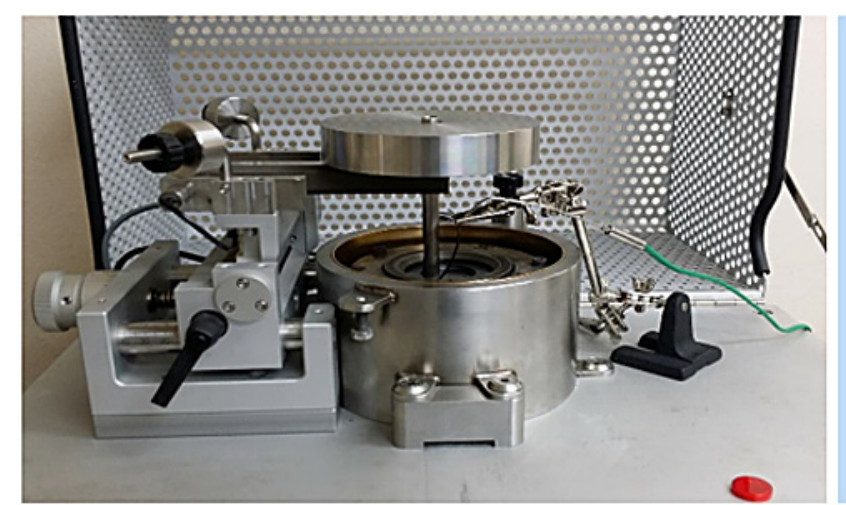

a)

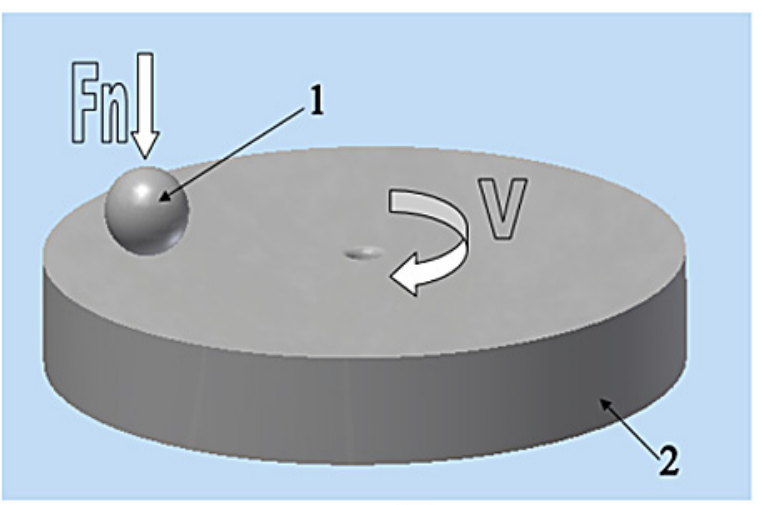

b)

Fig. 1. Schematic set-up of tribological tests, THT 1000 tribometer (a), ball-on-disc friction pair (b); 1 - counterbody; 2 - sample 


\section{RESULTS AND DISCUSSION}

Hardness tests were carried out on the surface and in the cross-section of the samples. Performed by the Rockwell C scale method, the measurements of hardness in the cross-section led to determination of changes in the deposited coating, interface and substrate.

The samples with two layers of padding have a hardness of $58 \mathrm{HRC}$, those with a single-layer pad - 56 HRC, while the hardness of the sample without padding is $51 \mathrm{HRC}$. The hardness of the cross-section of the coatings, the weld interface and the substrate before the tribological tests is shown in Fig. 2. The figure also shows hardness measurement points. The hardness of the coatings with two layers of padding varies between 55 and $56 \mathrm{HRC}$, that of the weld interface from 20 to $24 \mathrm{HRC}$, and that of the substrate from 31 to 32 HRC. One can observe that the substrate hardness decreases after welding from $51 \mathrm{HRC}$ to $32 \mathrm{HRC}$ (prior to welding, the surface hardness of the cultivator point is 51 HRC). This can be advantageous, since the entire surface has a hard outer layer and a soft substrate. Under dynamic loads, this combination of properties produces higher service life and impact load resistance.

Impact tests results demonstrate that the samples have high impact strengths. The impact strength of the coating with one layer of padding is $135 \mathrm{~J} / \mathrm{cm}^{2}$, while that of the coating with two layers is $147 \mathrm{~J} / \mathrm{cm}^{2}$. Analysis of the fractured samples demonstrates that the coating with two layers of padding (Fig. 3 a) has higher impact strength and ductility than the single-layer pad coating Fig. 3b).

The process of material wear depends on many factors such as friction pair material, contact temperature, roughness, surface hardness, load and slipping speed. The tribological tests were carried out on samples with one and two layers of padding. The objective of the tests was to determine properties of the coatings depending on impact loads, without a lubricant in room temperature. Two loads were applied: 5 and $20 \mathrm{~N}$. Volume wear was determined with Equation (2).

The volume wear of the samples with one layer of padding under a load of $5 \mathrm{~N}$ is $0.018 \mathrm{~mm}^{3}$. In turn, the volume wear of the samples with a double-layer pad is $0.045 \mathrm{~mm}^{3}$. A similar observation can be made for the samples after friction under a load of $20 \mathrm{~N}$. The volume wear of the single-layer pad samples is $0.012 \mathrm{~mm}^{3}$, while that of the samples with two layers of padding increases to $0.055 \mathrm{~mm}^{3}$. The volume wear of the counter bodies under a load of $5 \mathrm{~N}$ is $0.011 \mathrm{~mm}^{3}$ for the samples with one and two layers of padding alike. On the other hand, the volume wear of the single-layer pad samples under a load of $20 \mathrm{~N}$

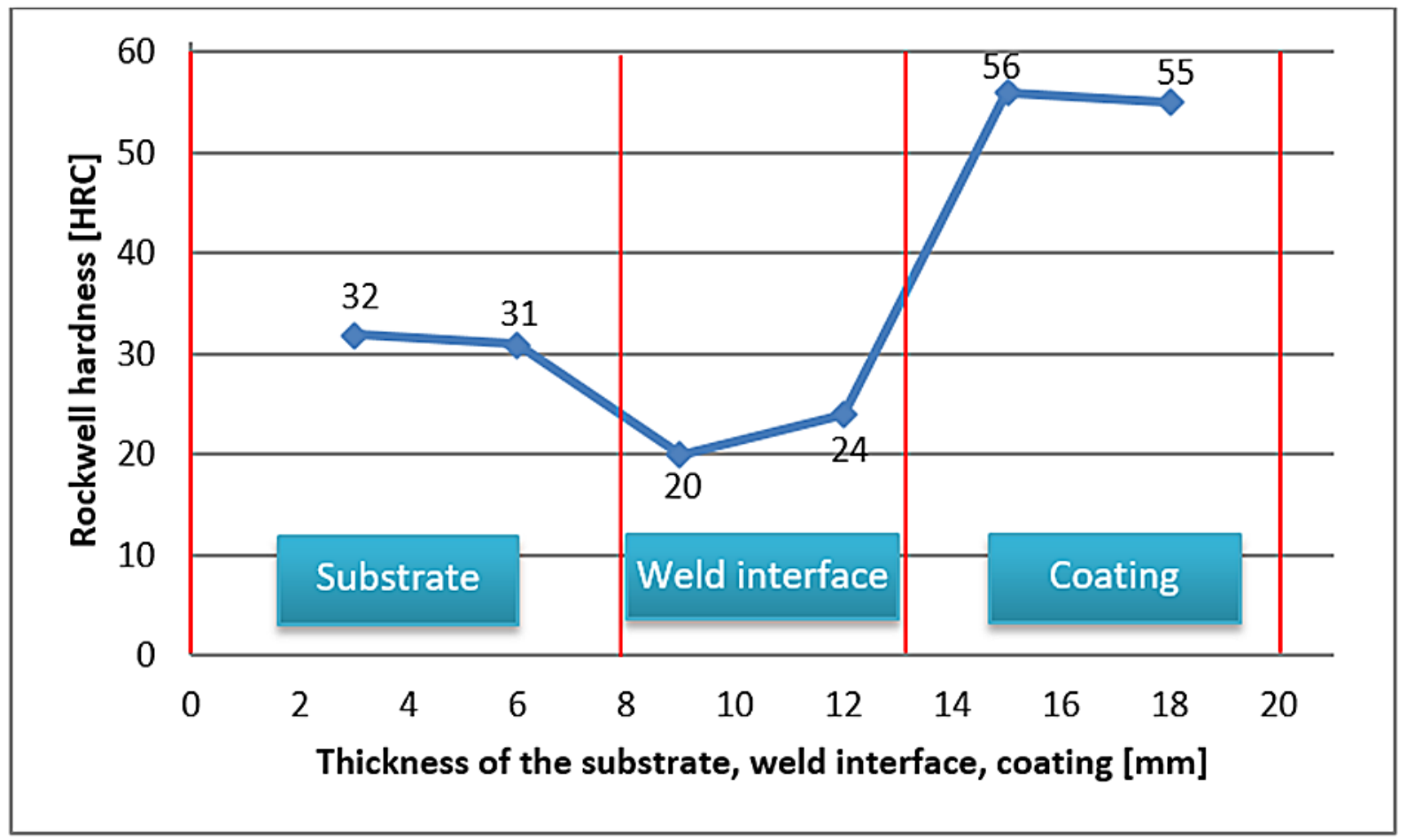

Fig. 2. Hardness in the cross section of coatings, weld interface and substrate 


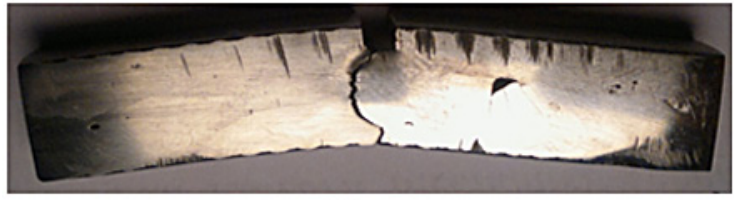

a)

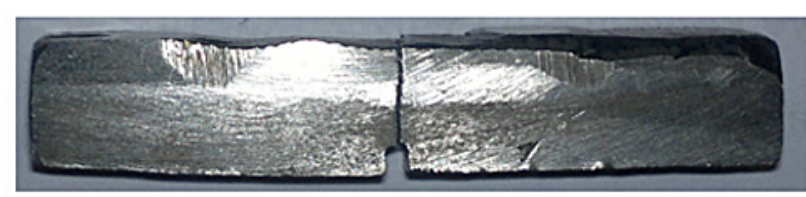

b)

Fig. 3. Fracture of the sample with a) double-layer pad, b) single-layer pad

load is $0.029 \mathrm{~mm}^{3}$. For the counterbodies of the samples with two layers of padding it increases to $0.034 \mathrm{~mm}^{3}$. Analysing volume wear results of the samples and the counterbodies, one can observe that the volume wear of the samples (single-layer pad coatings) and their counterbodies under 5 and $20 \mathrm{~N}$ loads is lower than that of the double-layer pad samples and their counterbodies. This confirms the recommendations of the electrode manufacturer that optimum properties of the coatings can be achieved even in the first pass, irrespective of applied the cooling rate. It is also worth noting that the volume wear of the samples loaded with $20 \mathrm{~N}$ is lower by $0.006 \mathrm{~mm}^{3}$ for the samples with one layer of padding and by $0.010 \mathrm{~mm}^{3}$ for the samples with two layers of padding. The increase in load to $20 \mathrm{~N}$ does not cause a sudden increase in the wear volume. Obtained results are similar.

The contacts stresses of the samples with one and two layers of padding under a load of $5 \mathrm{~N}$ are $1.091 \mathrm{GPa}$. However, under a load of $20 \mathrm{~N}-$ they are $1.732 \mathrm{GPa}$. Fig. 4 shows the wear volume of the samples with one and two layers of padding and of the counterbodies in room temperature, under two loads: 5 and $20 \mathrm{~N}$.
Load and friction path are important factors that must be taken into account when calculating and describing the rate of wear. Considering both load and friction path, the wear rate of the friction pair was calculated according to Equation 1. The wear rate and the friction coefficient determined in the tribological tests under 5 and $20 \mathrm{~N}$ loads are given in Figs. $5 \mathrm{a}$ and $\mathrm{b}$. Analysing obtained wear rates in terms of the number of pad layers, it can be observed that the wear rate of the samples with two layers of padding increases under both 5 and $20 \mathrm{~N}$ load. Under a load of $5 \mathrm{~N}$, the wear rate of the samples with one layer of padding is equal to $1.84 \times 10^{-5}$ $\mathrm{mm}^{3} \mathrm{~N}^{-1} \mathrm{~m}^{-1}$, while that of the samples with two layers of padding increases to $4.50 \times 10^{-5} \mathrm{~mm}^{3} \mathrm{~N}^{-1} \mathrm{~m}^{-1}$. On the other hand, under a load of $20 \mathrm{~N}$, the wear rate of the single-layer pad coatings is $0.30 \times 10^{-5}$ $\mathrm{mm}^{3} \mathrm{~N}^{-1} \mathrm{~m}^{-1}$, and that of the double-layer pad coatings is $1.38 \times 10^{-5} \mathrm{~mm}^{3} \mathrm{~N}^{-1} \mathrm{~m}^{-1}$. Under a load of $20 \mathrm{~N}$, the wear rate of the counterbodies of the samples with one layer of padding is equal to $0.72 \times 10^{-5}$ $\mathrm{mm}^{3} \mathrm{~N}^{-1} \mathrm{~m}^{-1}$, while that of the counterbodies of the samples with two layers of padding increases to $0.85 \times 10^{-5} \mathrm{~mm}^{3} \mathrm{~N}^{-1} \mathrm{~m}^{-1}$. The mean coefficient of friction under a load of $20 \mathrm{~N}$ for the samples with one layer of padding is 0.51 and for the samples with

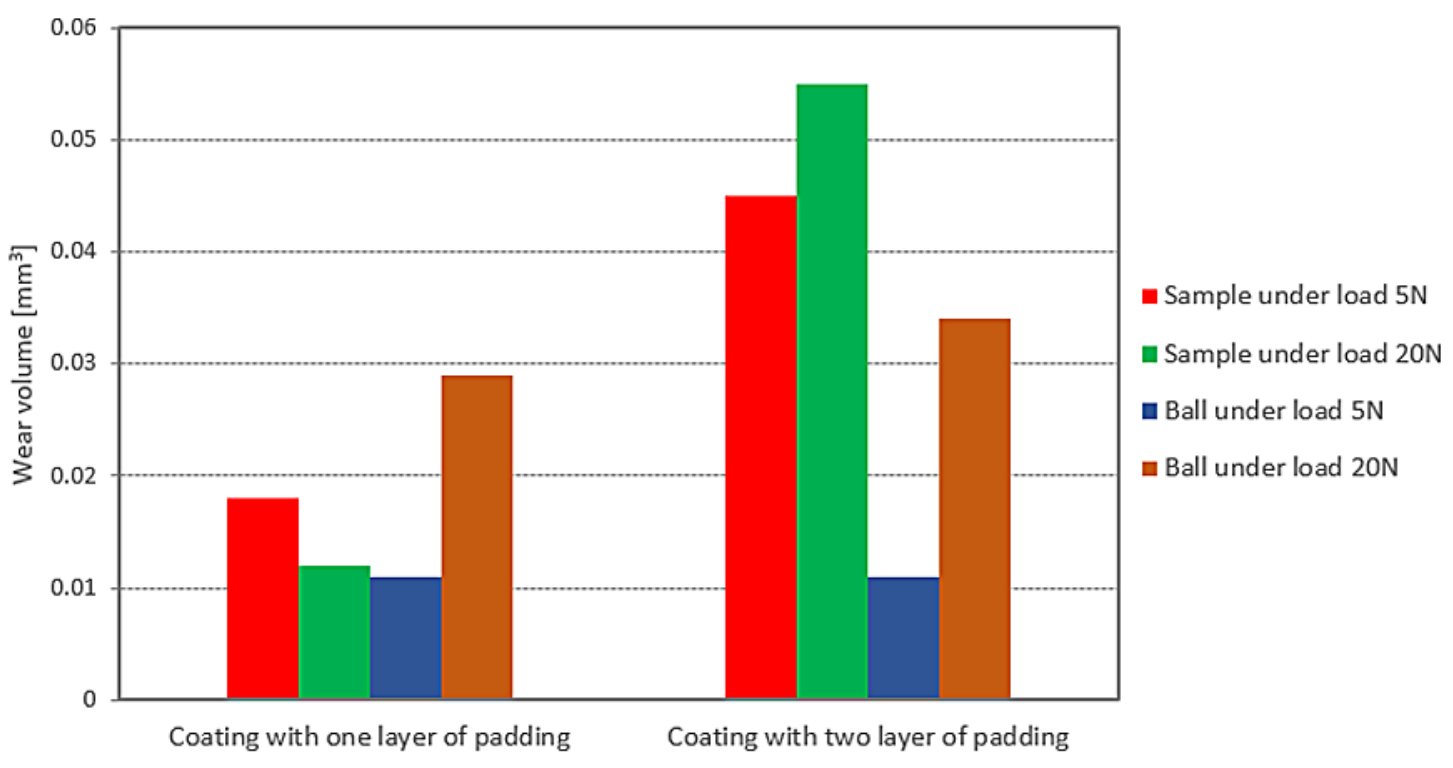

Fig. 4. Wear volume of single- and double-layer pad samples and counterbodies 
two layers of padding -0.57 . On the other hand, the maximum coefficient of friction is 0.58 and 0.72 , respectively. The mean coefficient of friction determined in the tribological tests for a load of $5 \mathrm{~N}$ is the same in both cases and amounts to 0.47 . On the other hand, the maximum friction coefficient for the combination with one layer of padding is 0.68 , and for two layers of padding - it is 0.66 .

In the tribological tests, the friction coefficient was measured on a continuous basis for two combinations: counterbody-single-layer pad coating and counterbody-double-layer pad coating. Fig. 6a shows variations in the friction coefficient under a load of $5 \mathrm{~N}$, while Fig. $6 \mathrm{~b}$ shows the behaviour of this parameter under a load of $20 \mathrm{~N}$, measured over a distance of $200 \mathrm{~m}$.

As shown in Fig. 6a, under a load of $5 \mathrm{~N}$, the friction coefficient of the two tested combinations (counterbody-single-layer pad coating and counterbody-double-layer pad coating) becomes stable only after a distance of $60 \mathrm{~m}$. Once stable, the coefficient of friction varies in a similar range for both cases. On the other hand, in both cases, under a load of $20 \mathrm{~N}$, the coefficient of friction becomes stable much faster after exceeding a $30 \mathrm{~m}$ friction path. In the tests, the friction coefficient is higher for the counterbody-double-layer pad coating combination than for the combination with a single layer of padding.

Results of the surface roughness measurements before and after friction, under loads of $5 \mathrm{~N}$ and $20 \mathrm{~N}$, for the single- and double-layer pad coatings are shown in Fig. 7. The results led to determination of the effect of the number of pad layers and load values on the $R a$ parameter of the friction pairs used in the tribological tests.

Before friction the roughness parameters $R a$ of the coatings with single- and double-layer pad are similar $-0.371 \mu \mathrm{m}$ and $0.367 \mu \mathrm{m}$, respectively. Under a load of $5 \mathrm{~N}$, the friction surface roughness increases to $0.421 \mu \mathrm{m}$ for the coating with one layer of padding and to $1.01 \mu \mathrm{m}$ for the coating with two layers of padding. On the other hand, under a load of $20 \mathrm{~N}$, the surface roughness decreases compared to its value before friction and is equal to 0.266 . The results show that the friction surface roughness of the coating with two layers of padding increases to $0.792 \mu \mathrm{m}$.

Microscopic examination led to identification of phenomena and wear mechanism in the material. Fig. 8 shows the SEM images (different enlargements) of wear tracks on the surface of singleand double-layer pad coatings under loads of $5 \mathrm{~N}$ and $20 \mathrm{~N}$. The friction surface has a flake-layered structure. There are differences in the shape and size of layers and flakes. Individual layers and flakes are located on different levels, and they overlap. They also show the presence of plastic strains that are more visible under a load of $20 \mathrm{~N}$ for both types of tested coatings (Figs. 8 e-h).

Flake-layered structures are formed as a result of plasticization of the surface layers. This occurs when the properties of a material in thin surface layers are conducive (low yield point or the deposition of wear products onto friction surface). The flake-layered structure of the friction surface is characterized by minimal wear because the thin layers are easily renewed.

\section{CONCLUSIONS}

This paper investigated the properties of single- and double-layer pad coatings deposited on the working surface of cultivator points. The deposition of coatings by welding methods increases the properties of consumables. The tools and IT algorithms were used to collect and process the results of experimental research. Based on the results, the following conclusions can be formulated: 1. After welding, the hardness of the single- and double-layer pad coatings is similar, respectively $56 \mathrm{HRC}$ and $58 \mathrm{HRC}$. On the other hand, the hardness of the substrate decreases after welding from $51 \mathrm{HRC}$ to $32 \mathrm{HRC}$.

2. The coatings with two layers of padding have higher impact strength and ductility $\left(147 \mathrm{~J} / \mathrm{cm}^{2}\right)$ than the coatings with one layer of padding $\left(135 \mathrm{~J} / \mathrm{cm}^{2}\right)$.

3. The coatings with one layer of padding have a lower wear rate than those with two layers of padding. It has been found that their wear rate is the lowest under a load of $20 \mathrm{~N}$. The volume wear of the samples (single-layer pad) and their counterbodies under 5 and $20 \mathrm{~N}$ loads is several times lower than that of the coating with two layers of padding and their counterbodies.

4. Analysing the dependence between wear rate and the number of pad layers, it can be observed that the wear rate increases for the coatings with two layers of padding under 5 and $20 \mathrm{~N}$ loads alike.

5 . The roughness $R a$ of friction surface of the coating with one layer of padding decreases under a load of $20 \mathrm{~N}$, when compared to its initial roughness. Prior to friction, the roughness $R a$ is $0.371 \mu \mathrm{m}$ while after friction $-0.266 \mu \mathrm{m}$. On the other hand, under a load of $5 \mathrm{~N}$, the roughness 


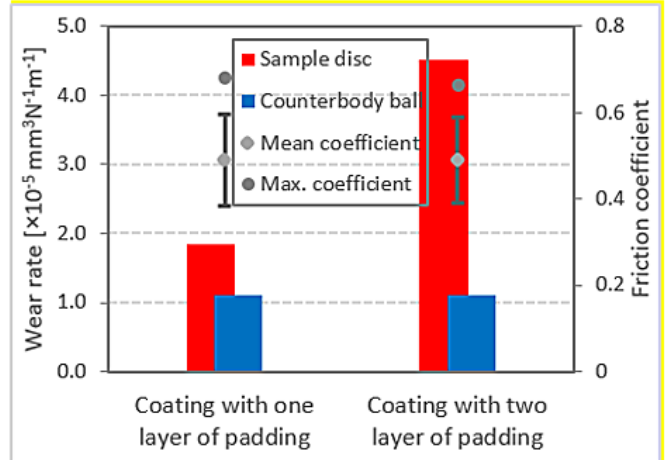

a)

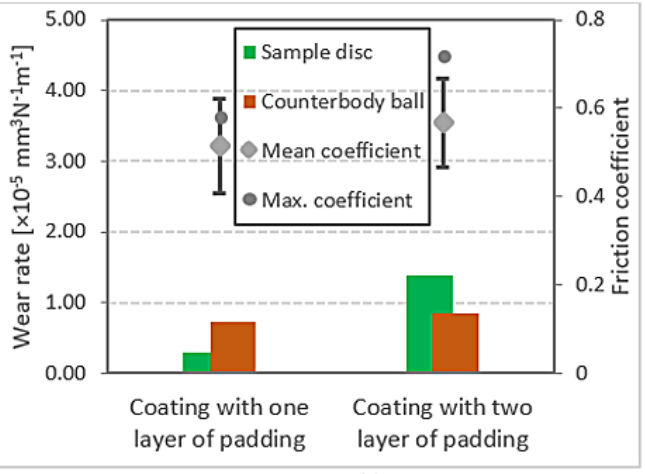

b)

Fig. 5. Wear rate and friction coefficient versus load of: $5 \mathrm{~N}$ (a) and $20 \mathrm{~N}$ (b)

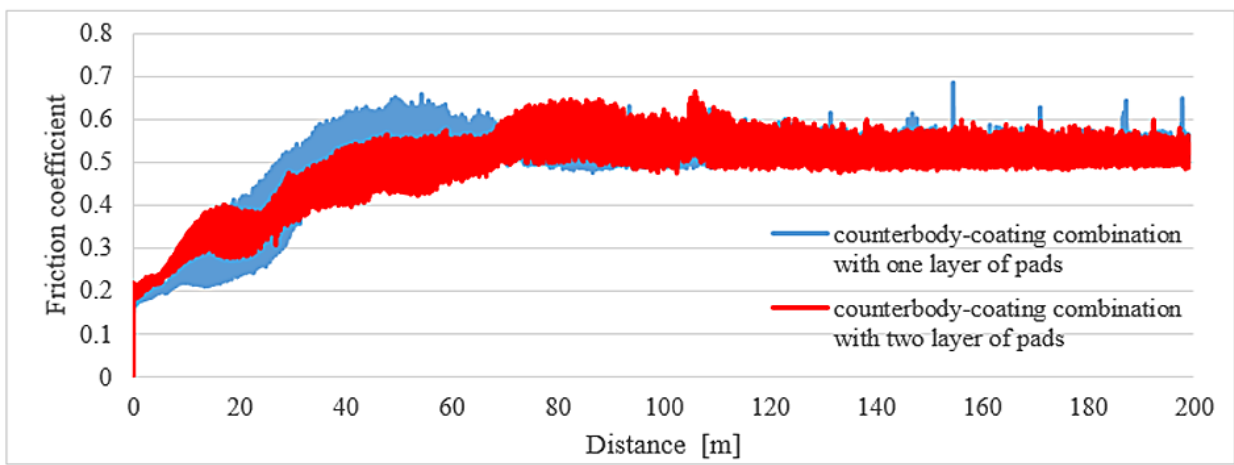

a)

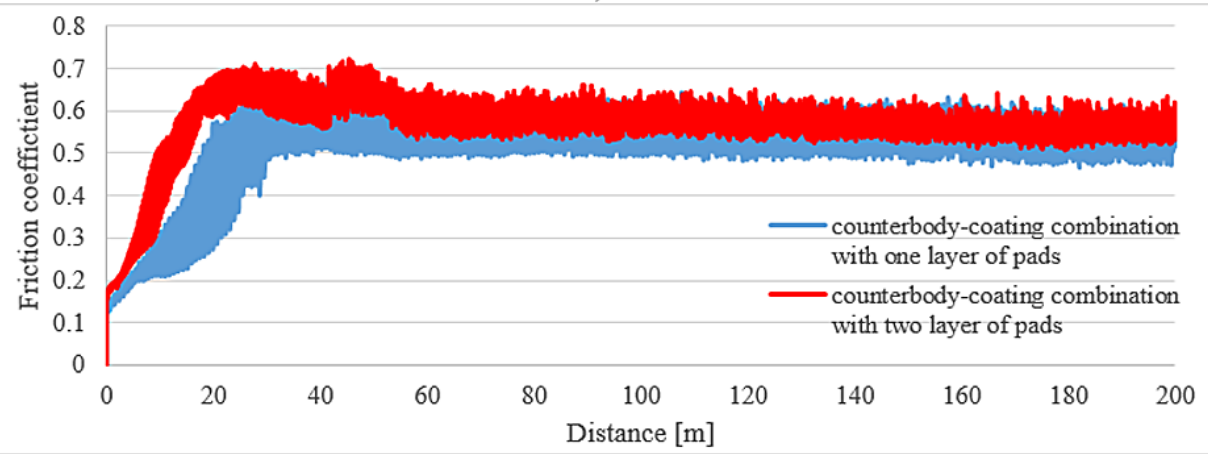

b)

Fig. 6. Variations in the friction coefficient under load of $5 \mathrm{~N}$ (a) and $20 \mathrm{~N}$ (b)

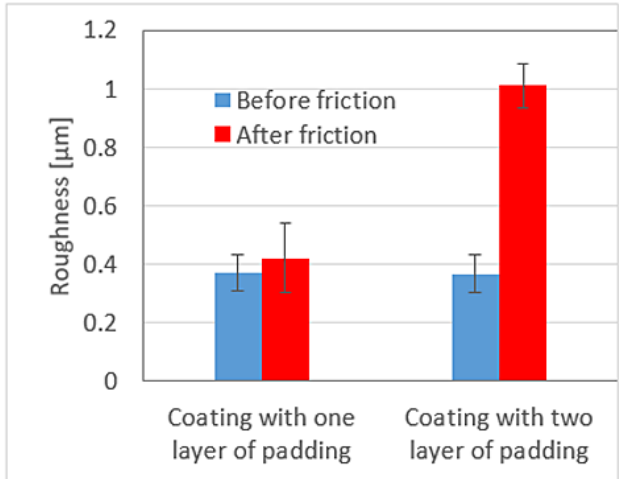

a)

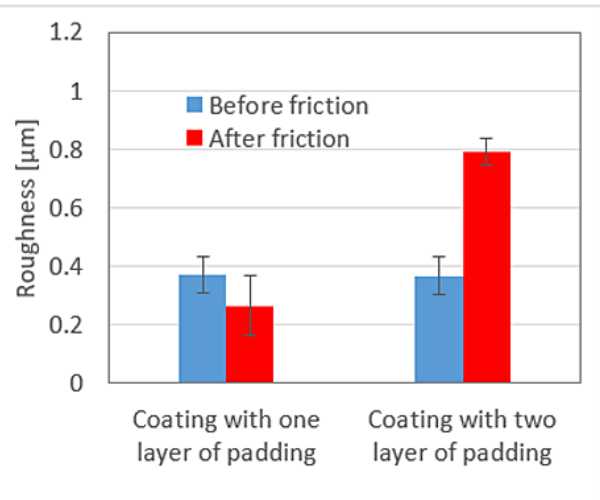

b)

Fig. 7. Roughness Ra of coatings with one and two layers of padding under load of: 5 N (a) and 20 N (b) 


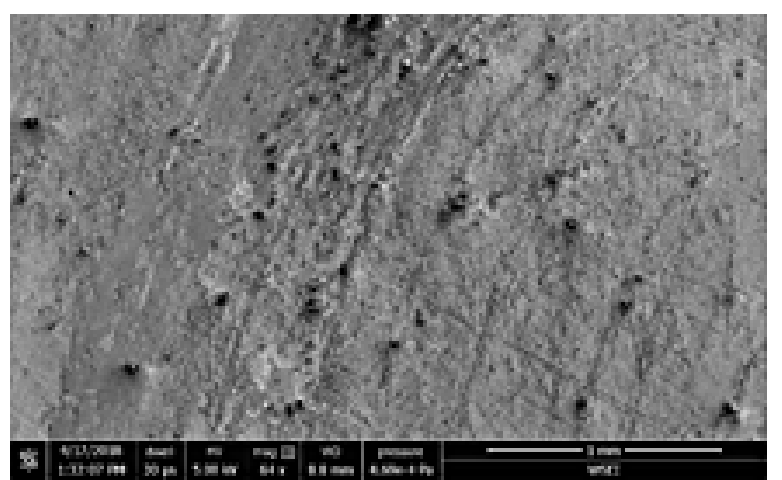

a)

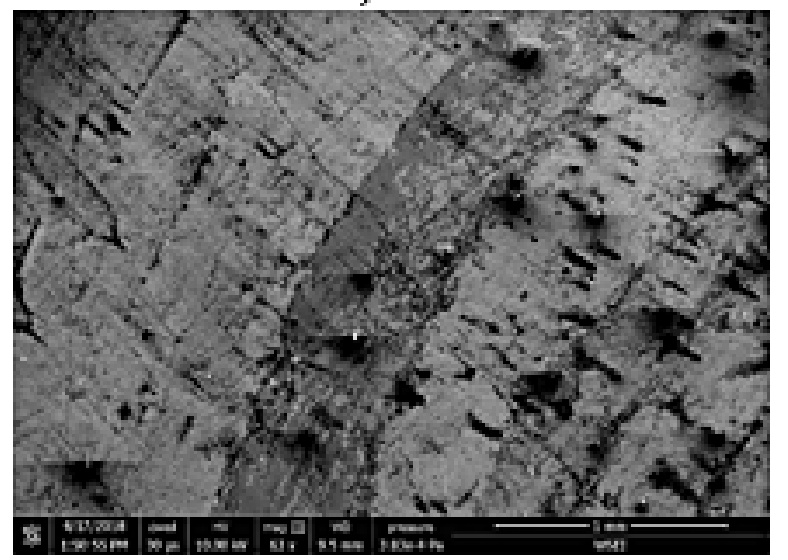

c)

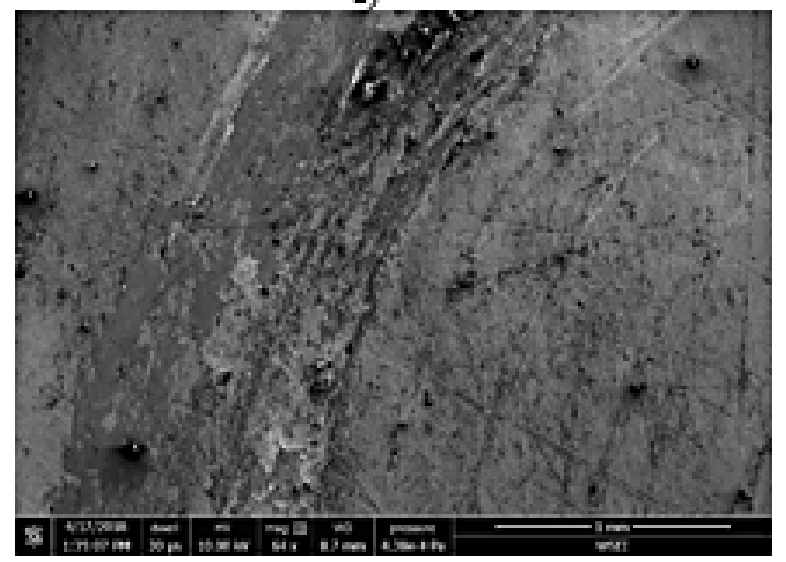

e)

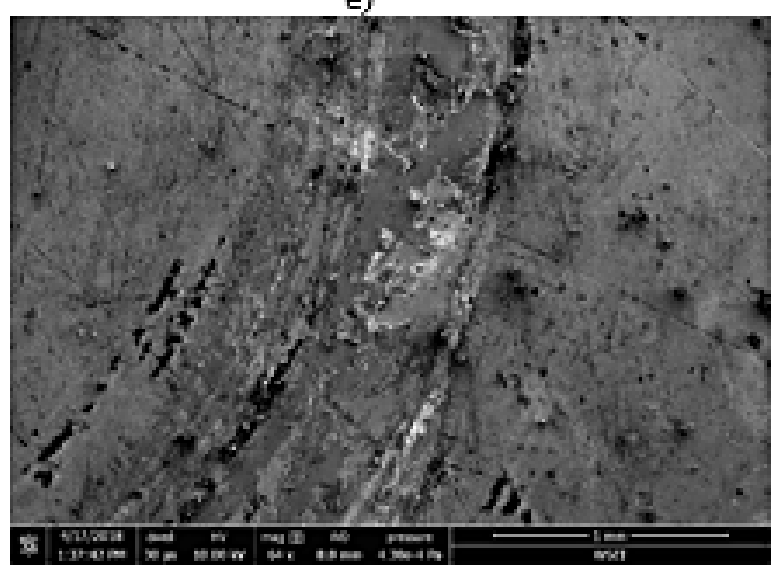

g)

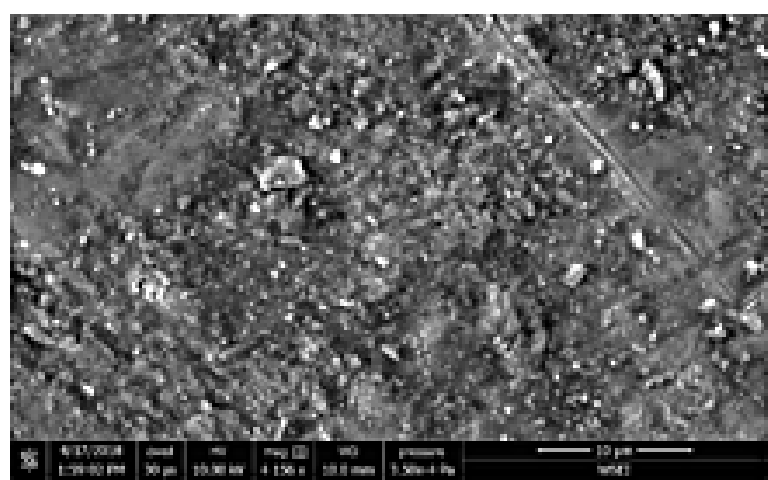

b)

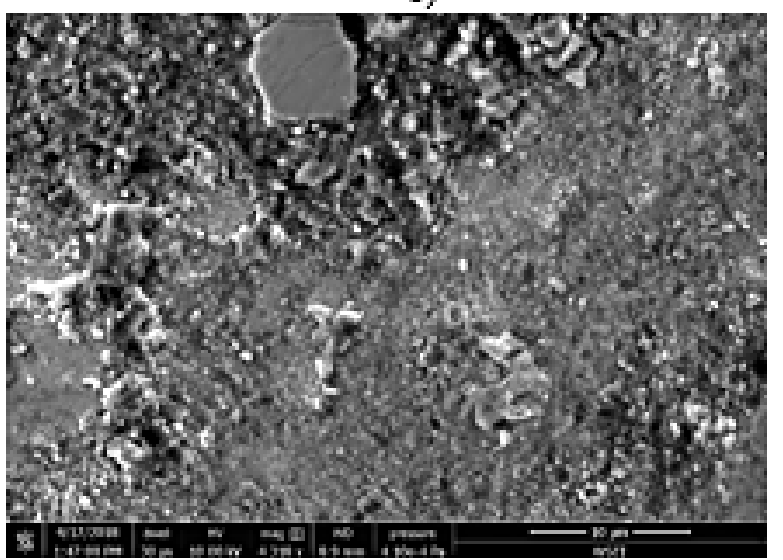

d)

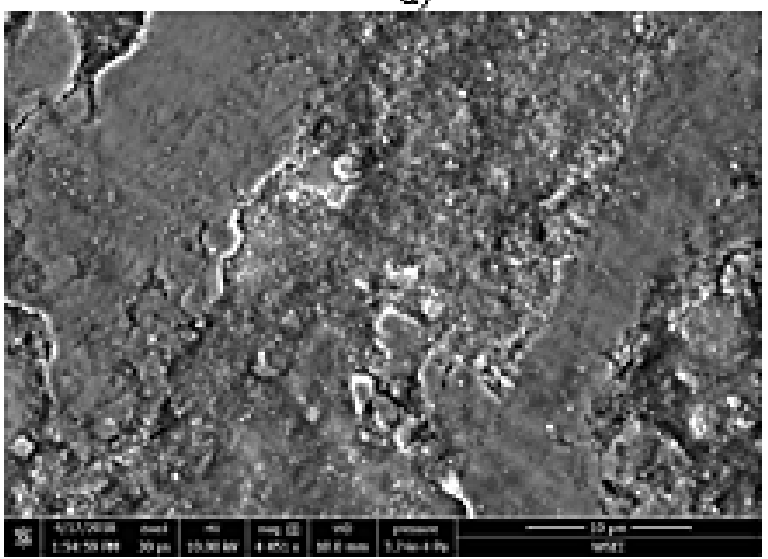

f)

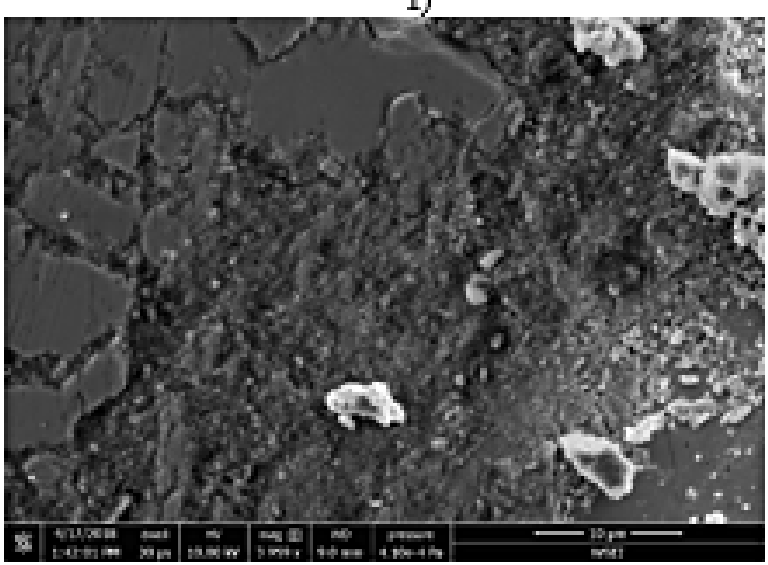

h)

Fig. 8. Coating surface after friction: under load of $5 \mathrm{~N}$ applied to coatings with one layer of padding (a-b) and two layers of padding (c-d) and under load of $20 \mathrm{~N}$ applied to coatings with one layer of padding (e-f) and two layers of padding (g-h) 
slightly increases (up to $0.421 \mu \mathrm{m}$ ). In contrast, for the above loads, the roughness of the doublelayer pad coating increases about 2-3 times.

6. The analysis of wear tracks has revealed that the friction surfaces have a flake-layered structure of varying flake shapes and sizes. The surfaces also show the presence of strains that are more visible under a load of $20 \mathrm{~N}$ for the coatings with both one layer and two layers of padding.

\section{REFERENCES}

1. Müller M., Hrabě P., Overlay materials used for increasing lifetime of machine parts working under conditions of intensive abrasion, Research in Agricultural Engineering, 59(1), 2013, 16-22.

2. Buchely M.F., Gutierrez J.C., León L.M., Toro A., The effect of microstructure on abrasive wear of hardfacing alloys, Wear, 259, 2005, 52-61.

3. Giovanni, S., Friction and Wear, Methodologies for Design and Control, Springer 2015.

4. Purkayastha S., Dwivedi D.K., Abrasive and erosive wear performance of rare earth oxide doped $\mathrm{Ni} / \mathrm{WC}$ coatings, Journal of Tribology, 136(1), 2013, 602-609.

5. Lemecha M., Napiórkowski J., Rosiak M., Effect of friction speed on wear intensity in abrasive soil mass, MATEC Web of Conferences, IManE\&E 2017, 112, 2017, 6 .

6. Manuwa S.I., Evaluation of soil/materiali friction and adhesion of akure sandy clay loam soils in southwestern Nigeria, Advances in Natural Science, 5(1), 2012, 41-46.

7. Napiórkowski J.,Analiza właściwości glebowej masy ściernej w aspekcie oddziaływania zużyciowego, Tribologia, 5, 2010, 53-62.

8. Napiórkowski J., Lemecha M., Ligier K., Analiza właściwości tribologicznych napoin z zawartością niobu w glebowej masie ściernej, Tribologia, 3, 2015, 109-120.

9. Napiórkowski J., Szczyglak P., Kołakowski K., Analiza geometrii ziaren glebowej masy ściernej, Inżynieria Rolnicza, 4(147), 2013, 237-247.

10. Napiórkowski J., Zużyciowe oddziaływanie gleby na elementy robocze narzędzi rolniczych," Inżynieria Rolnicza, 12 (72), 2005, Rozprawy habilitacyjne nr 17.

11. Stabryła J., Starczewski L., Oddziaływanie wodoronośnych składników gleby na zużycie ścierne narzędzi rolniczych, Problemy Eksploatacji, 1, 2006, 199-207.

12. Kostencki P., Stawicki T., Temperatura warstwy wierzchniej elementów roboczych narzędzi rolniczych przeznaczonych do uprawy gleby. Części - obiekty badań i warunki ich pracy, kontaktowe pomiary temperatury, Tribologia, 2, 2015, 41-58.

13. Kostencki P., Łętkowska B., Nowowiejski R., Polowe badania odporności na zużycie ścierne lemieszy płużnych wykonanych ze stali z dodatkiem boru, Tribologia, 3, 2013, 49-79.

14. Napiórkowski J., Pękalski G., Kołakowski K., Badanie struktur i zużywania powłok napawanych w glebowej masie ściernej, Tribologia, 3, 2012, 111-117.

15. Napiórkowski J., Ligier K., Lemecha M., Wpływ technologii nanoszenia warstw Fe-C-Cr-B na właściwości zużyciowe w glebowej masie ściernej, Mechanik, 4, 2015, 92-97.

16. Barszcz M., Paszeczko M., Lenik K., Selforganization of friction surface of Fe-Mn-C-B coating with increased resistance to abrasion, Archives of Metallurgy and Materials, 60, 2015, 2651-2656.

17. Yüksel N., Sahin S., Wear behawior-hardnessmicrostructure relation of $\mathrm{Fe}-\mathrm{Cr}-\mathrm{C}$ and $\mathrm{Fe}-\mathrm{Cr}-\mathrm{C}-\mathrm{B}$ based hardfacing alloys, Materials and Design, 58, 2014, 491-498.

18. Gualco A., Svoboda H., Surian E., Study of abrasive wear resistance of Fe-based nanostructured hardfacing, Wear, 360-361, 2016, 14-20.

19. Lin C., Chang C., Chen J., Hsieh C., Wu W., Microstructure and wear characteristics of highcarbon Cr-based alloy claddings formed by gas tungsten arc welding (GTAW), Surface \& Coatings Technology, 205, 2010, 2590-2596.

20. Wang X., Zou Z., Qu S., Microstructure of Fe-Based Alloy Hardfacing Coating Reinforced by TiC-VC Particles, Journal of Iron and Steel Research, 13(4), 2006, 51-55.

21. Correa E.O., Alcântara N.G., Valeriano L.C., Barbedo N.D., Chaves R.R., The effect of microstructure on abrasive wear of a Fe-Cr-C-Nb hardfacing alloy deposited by the open arc welding process, Surface \& Coatings Technology, 276, 2015, 479-484.

22. Pashechko M., Dziedzic K., Barszcz M., Study of the structure and properties of wear-resistant eutectic $\mathrm{Fe}$ Mn-C-B-Si-Ni-Cr coatings, Powder metallurgy and metal ceramics, 52, 2013, 469-476.

23. Liu H., Song Z., Cao Q., Chen S., Meng Q., Microstructure and properties of $\mathrm{Fe}-\mathrm{Cr}$-C hardfacing alloys reinforced with TiC-NbC, Journal of iron and steel research international, 23(3), 2016, 276-280.

24. Pashechko M., Dziedzic K., Barszcz M., Study of coatings obtained from alloy Fe-Mn-C-B-Si-Ni-Cr, Advances in Science and Technology - Research Journal, 31(10), 2016, 194-198.

25. Badisch E., Katsich C., Winkelmann H., Franek F., Manish R., Wear behavior of hardfaced Fe-Cr-C alloy and austenitic steel under 2-body and 3-body conditions at elevated temperature, Tribology International, 43, 2010, 1234-1244.

26. Bar-Hen M., Etsion I., Experimental study of the effect of coating thickness and substrate roughness on tool wear during turning, Tribology International, 110, 2017, 341-347.

27. Kostencki P., Stawicki T., Białobrzeska B., Durability and wear geometry of subsoiler shanks provided with sintered carbide plates, Tribology International, 104, 2016, 19-35. 